\title{
Comparative study of different sports professional students majoring force sense - To Take the Department of Physical Education in Xinzhou normal University as an Example
}

\author{
Lihong YAN \\ School of Graduate \\ Tianjin University of Sport \\ Tianjin,300381,China
}

\begin{abstract}
This paper used literature information law, experiment law and mathematical statistics law, research method, from 40 boys selected in random in Xinzhou normal college sports department at grade 4 and 2 , in static force sexual (holding electronic grip meter) and power sexual (threw weight of $550 \mathrm{~g}$ weights) two species State Xia, we use electronic grip meter, experiment equipment, and test their hand sense, and test results are for comparison analysis. Results showed that static experimental conditions have no significant differences between students. Under dynamic conditions, students ' sense of optional sports are better than other students. This article explains the reasons for these phenomena, to explore the factors influencing the perception of ways to improve students ' sense, for physical education and training it provides the theoretical basis and ultimately to help students improve athletic performance.
\end{abstract}

Keywords- PE; sense of accuracy performance

\section{INTRODUCTION}

To people with griping size feeling ability, they can not only feel the nuances of effort size afterwards, but also actively according to certain standards control their own strength. This strength ability is hard to identify and control . The human body for the understanding of force is the feeling of human body muscle force; muscle force accuracy is higher, the better the sense of force will be. Muscle strength is when human body under the action of the nervous system, the ability to overcome or against resistance, and it is also an important part of human body system and the basic power source. In today's competitive sports, on muscle strength training and research, it has the vital role; it is one of the important factors that athletes get good grades. To the improvement of muscle force, therefore, the accuracy is very important. When human body is under a state of dynamic, what are the influence factors of hand strength feeling, how muscle movement feel, what are the ways of feeling strength to improve our hands, how to make use of the special characteristics to improve the elective students hands feeling, we need to further study all these problems.

\section{THE RESEARCH OBJECT AND METHODS}

\section{A. The object of study}

This study fastens xinzhou normal college 40 sophomore and senior male students as the research object.

\section{B. The research methods}

\section{1) Literature}

Through China hownet, China journal full-text database retrieval systems and other web site, the hard feeling of relevant journals, books and research papers, etc., we collect information related to this topic, the research achievements from other disciplines as the theoretical basis of this paper.

\section{2) Experiment method}

Using electronic dynamometer, water bottles, tape measure, such as equipment, according to each experimental equipment of the experimental method for the research object, record the result of the experiment.

3) mathematical statistics

Use SPSS 17.0 statistical software, statistical processing of the test data for scientific, and the results of the analysis conclusion.

\section{EXPERIMENT CONTENT}

A. dominant hand muscle testing - the feeling of throwing a weight of $550 \mathrm{~g}$

Equipment and materials: weight is $550 \mathrm{~g}$ water bottles, tape, and paper

1) Methods and procedures:

Subjects at first grind water bottles, and determine its farthest distance. Take half of the distance (X) as standard. Asked to be uniform trial practice and slow speed 3 times half of the distance, and remember the feeling of strength at this time. The experimenter for participants wear goggles asked participants to copy half maximum grip strength three times, namely under the condition of no feedback as far as possible each time the feeling of hard and stimulate the sensation of equal standard, document the results of each copy $(\mathrm{X} 1, \mathrm{X} 2, \mathrm{X} 3)$, there are 10 seconds interval in each experiment. 


\section{2) The results and interpretation:}

Take three times the sum of absolute value of error (I $\mathrm{X} 1-|| \mathrm{X} 2+\mathrm{X}-\mathrm{X}|+| \mathrm{X} 3-\mathrm{X} \mid$ ) average, divide them by the farthest distance, get the evaluation standard. Its value is smaller means that the accuracy is better [5].

\section{STUDIES OF FEELING OF THE ELECTIVE STUDENTS HAND FORCE BETWEEN THE COMPARATIVE UNDER THE CONDITION OF DYNAMIC EXPERIMENTS}

\section{A. The elective students throwing conditions laid hands on him push the contrast research of feeling}

In the sophomore and senior, we specially selected 40 male students randomly as the research object

Table 1 overall contrast of hand hard feeling between various elective students

\begin{tabular}{|c|c|c|c|c|c|}
\hline Elec & basket & badmi & Volley & ten & \\
\hline tive & ball & nton & ball & nis & $\begin{array}{l}\text { rtial } \\
\text { arts }\end{array}$ \\
\hline Gra & 0.024 & 0.0312 & 0.0434 & 0.0 & 0 \\
\hline de & 4 & & & 478 & 583 \\
\hline
\end{tabular}

The table shows that in overall throwing the weight of $550 \mathrm{~g}$ weight moves, basketball elective students hand feeling is the best. Comparing with basketball as the core, it can be seen that the basketball with other elective hand hard feeling have differences, $\mathrm{P}=0.025,0.016,0.013,0.01<$ $0.025,0.016,0.013,<0.05$, basketball and badminton, volleyball, tennis elective students hand hard feeling difference was not significant. $\mathrm{P}=0.001,0.000<0.001$, indicating that the basketball elective students and martial arts, athletics, gymnastics elective students hand hard feeling have significant difference. Comparing with badminton elective as the core, $\mathrm{P}=0.064,0.073>0.05$, badminton and volleyball, tennis elective students hand feeling there was no significant difference. $\mathrm{P}=0.005,0.000<0.005$, which indicates that badminton elective students and martial arts, athletics, gymnastics elective students hand hard feeling have significant difference. Comparing with volleyball elective students as the core, we can see the hand of volleyball and tennis elective students hard feeling there was no significant difference, and martial arts, athletics, aerobics has significant difference. Comparing with martial arts and athletics as the core, there was no significant difference between the hand of martial arts, athletics, gymnastics elective students hard feeling.
Table 2 the hand hard feeling between specially selected students of single factor variance contrast

\begin{tabular}{|c|c|c|c|c|}
\hline $\begin{array}{c}\text { Choosing } \\
1\end{array}$ & $\begin{array}{c}\text { Choosing } \\
2\end{array}$ & $\begin{array}{c}\text { Mean } \\
\text { difference }\end{array}$ & $\begin{array}{c}\text { Standard } \\
\text { difference }\end{array}$ & $\begin{array}{l}\text { standard of } \\
\text { significance }\end{array}$ \\
\hline \multirow[t]{8}{*}{ Basketball, } & badminton & -.0069000 & .0089019 & 025 \\
\hline & Volleyball & $-.0190600^{*}$ & .0089019 & 016 \\
\hline & Tennis & $-.0234800^{*}$ & .0089019 & 013 \\
\hline & Martial & $-.0339600^{*}$ & .0089019 & 001 \\
\hline & arts & & & \\
\hline & Track and & $-.0537800^{*}$ & .0089019 & 000 \\
\hline & field & & & \\
\hline & Aerobics & $-.0503000^{*}$ & .0089019 & 000 \\
\hline \multirow[t]{6}{*}{ badminton } & Volleyball & -. 0121600 & .0089019 & 064 \\
\hline & Tennis & -.0165800 & .0089019 & 073 \\
\hline & Martial & $-.0270600^{*}$ & .0089019 & 005 \\
\hline & arts & & & \\
\hline & $\begin{array}{l}\text { Track and } \\
\text { field }\end{array}$ & $-.0468800^{*}$ & .0089019 & 000 \\
\hline & Aerobics & $-.0434000^{*}$ & .0089019 & 000 \\
\hline \multirow[t]{4}{*}{ Volleyball } & Tennis & -.0044200 & .0089019 & 183 \\
\hline & $\begin{array}{l}\text { Martial } \\
\text { arts }\end{array}$ & -. 0149000 & .0089019 & 001 \\
\hline & $\begin{array}{l}\text { Track and } \\
\text { field }\end{array}$ & -. 0347200* & .0089019 & 001 \\
\hline & Aerobics & $-.0312400^{*}$ & .0089019 & 002 \\
\hline \multirow[t]{3}{*}{ Tennis } & $\begin{array}{l}\text { Martial } \\
\text { arts }\end{array}$ & -.0104800 & .0089019 & 001 \\
\hline & $\begin{array}{l}\text { Track and } \\
\text { field }\end{array}$ & $-.0303000^{*}$ & .0089019 & 002 \\
\hline & Aerobics & $-.0268200^{*}$ & .0089019 & 005 \\
\hline \multirow[t]{2}{*}{$\begin{array}{l}\text { Martial } \\
\text { arts }\end{array}$} & $\begin{array}{c}\text { Track and } \\
\text { field }\end{array}$ & -. 0198200* & .0089019 & 063 \\
\hline & Aerobics & -. 0163400 & .0089019 & 077 \\
\hline $\begin{array}{l}\text { Track and } \\
\text { field }\end{array}$ & Aerobics & -.0034800 & .0089019 & 699 \\
\hline
\end{tabular}




\section{CONCLUSIONS}

\section{A. The conclusion}

1) Under the condition of static experiments were not different between different elective students sense of force.

2) Under the condition of dynamic experiment, while students throwing gesture, basketball elective students have best sense of force. Ball of elective student's sense of force is better than that of the ball specially selected students.

3) Under the condition of dynamic experiment, the students do the action of throwing, badminton, tennis elective students are best. Ball of elective student's sense of force is better than that if the ball specially selected students.

\section{B. advices}

1) According to the special characteristics of formulating feasible training plan, control the intensity of training time, training, strict, take appropriate ways to practice. Project, different training methods should also be different.

2) In hard feeling physiological sensitive period by applying the methods of the reasonable arrangement training, seize the age advantage make up for the defect of genetic as far as possible.

3) In the teaching process, teachers should pay attention to give students timely oral or actions, and we suggest that strengthen students for hard experience, make some targeted to improve the muscle sense to design method of practice, let the students sense of muscle force be more precise, to help students improve their performance.

4) The students should pay attention to their muscles feeling and establish solid contact with the correct action.

\section{References}

[1] Yang Bomin. Sports psychology textbooks. Sports science society of China, 1984125-126.

[2] Gao Jian, Yang Dan. Our country outstanding decathlon athletes mental ability test and research [J]. Journal of Chinese sports science and technology, 2000,09:29 and 30.

[3] Yang Haiping. 12 of different level basketball player perceptions index of test and analysis [J]. Journal of Beijing sports university, 2005,01:52-54

[4] Yang Bomin. Psychological experiment outline. Beijing: Peking University press, 1989132-135.

[5] Cai Rneming. our country excellent archers muscle force and hand stability test and analysis [J]. Journal of guangzhou institute of sports, 1989,01:111-114.

[6] Gao pengfei, guo-fu xu. Free throws on the impact of awareness training on free throw accuracy experimental study $[\mathrm{J}]$. Journal of capital institute of physical education, 2010 01:25 to 28.

[7] Zhang Lin FanJinDong. Free throws in the importance of the game and the main factors influencing the shooting [J]. Journal of sports science research, 1997, (3) : 30-34.

[8] Hai-ping Yang. different level basketball player 7 perceptual indexes of the test and analysis [J]. Journal of sports science, 2004, 01:17-19.

[9] Si Lige, Tian Gengyun, Yang Haiping. Improving accuracy play hard sense teaching preliminary study [J]. Journal of shandong sports institute, 1994,01:70-72.

[10] Huang Xiting. Sports psychology [M]. Shanghai: east China normal university press, 2003.

[11] Zhang Liwei, Mao Zhixiong. Sports psychology [M]. Shanghai: east China normal university press, 2003:44.

[12] CongHu ping. Sports statistics [M]. Beijing: higher education press, 2007.218 220225-228.

[13] Dongli wang, Wei Ping, hou can. In the movement process of the athletes inner sense perception ability of simple diagnostic method [J]. Journal of shandong sports science and technology, 1997, 12 (6) : 4749.

[14] Tian Maijiu. XiangQun training theory [M]. Beijing: people's sport publishing house, 1998.253, 262279-280.Self-monitoring.

[15] Donhqi, Tao sha. Action and psychological development [M]. Beijing: Beijing normal university press, 2002:25 to 27. 